\title{
Remote home-based education as a new phenomenon in the time of the covid-19 pandemic - the experience of Czech families
}

\author{
Yvona Kostelecká, Tereza Komárková, Veronika Novotná
}

Abstract: In March 2020 a state of emergency was declared in the Czech Republic in response to the COVID-19 pandemic, which that resulted in the closures of schools. The provision of education continued through mandatory remote home-based education. The aim of this study is to use in-depth interviews to show how Czech families with children at the primary levels of education have coped with this situation. Based on a qualitative analysis, it is possible to state that the families who participated in the research were coping well with the situation and had come up with effective arrangements both for providing education and for fulfilling other responsibilities. The research also revealed that many families consider this to be very demanding time. At the same time, we identified that the way how families tackled the situation of home-based education depended on several factors. The key role was played by the school factor, namely the quality of remote education offered by school and the communication between the school and the parents. The analysis showed that although the quality of communication and remote education offered by school improved between spring 2020 and autumn 2020, schools still have much room to improve the education provided.

Key words: COVID-19 pandemic, lockdowns, remote education, home-based education

\section{Introduction}

The global crisis that the COVID-19 pandemic as given rise to has had an impact well beyond the sphere of public health, affecting almost every 
area of public life, including education (Gouëdard, Pont \& Viennet, 2020). National governments' efforts to contain the spread of the pandemic led in many states to the introduction of strict measures to limit physical proximity - i.e. lockdowns (ibid.). The need to practice social distancing has affected every level of education and in many cases led to the temporary closure of schools (Reimers \& Schleicher, 2020). Schools in at least 188 countries around the world have been closed during the COVID-19 pandemic, and this has impacted the education of almost 1.6 billion children and young people (Gouëdard, Pont \& Viennet, 2020).

'Learning interruptions' can have significant negative effects on students' performance as they lose educational opportunities and may also lose some of the knowledge and skills they have already developed (see, e.g., Cooper et al., 1996 in OECD, 2020). Consequently, governments have tried to ensure the continuity of students' academic education by means of various 'alternative modalities of education' that do not require students to be physically present in schools (Reimers \& Schleicher, 2020).

In many countries a solution was found in the form of 'remote home-based education"1. This mode of learning depends on households being equipped with ICT technology, and it places a heavy demand on schools and families working together, because although education is directed by the school, it takes place in the student's home. This has presented families and schools with a serious challenge; almost overnight parents had to adapt the home environment and their own time to the immediate educational needs of their children, and teachers had to transform traditional face-to-face forms of education into remote forms (e.g. online classes, instructional packages such as textbooks, worksheets, printouts, educational television programmes, existing online instructional resources, educational videos).

This situation was a new experience and challenge for students as well. They had to continue their learning without the in-person teaching support of teachers, which puts a greater demand on their self-discipline and their ability to organise their time (Barhoumi et al., 2020). Online forms of education, moreover, require a higher level of ICT skills and more time spent in front of screen media, and this may conflict with some parents' views (Holloway, Green \& Livingstone, 2013; Parczewska, 2020).

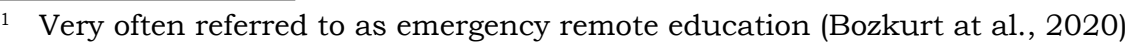


Lee et al. (2021) note that the pandemic has significantly interfered with the everyday lives of many families. This has primarily been true of families with young school-age children, who usually require not just care and support from their parents when learning but even the parents' immediate participation in the learning process, despite the fact that many parents have had to continue to perform their regular work responsibilities and under normal circumstances would not have chosen this mode of education. As Parczewska (2020) put it, the state assigned parents the task of being their children's teachers and the organisers of their children's free time. So families could cope with this situation, many mothers began working from home (Yamamura \& Tsutsui, 2021) - if that was an option for them. For a time, home-based learning ceased to be the choice of parents and became their de facto responsibility (ibid.). Lee et al. (2021) regard this shift in education out of the school and into the home as unprecedented in the context of recent American history, but it is an unprecedented situation in education generally all over the world.

Although many countries impacted by the pandemic were able to organise the continuation of education, there have been widespread fears as to whether the alternative modes of teaching that have been set up are effective, and whether students are learning less than they would have had they been in school, because problems ensuring the provision of education have been apparent in the past during other crises (Shavers, 2005; Peek \& Richardson, 2020). Some studies, moreover, have highlighted the limited effectiveness of home-based learning during the COVID-19 pandemic (Engzell, Freya \& Verhagen, 2020).

Although these concerns are relevant, a number of studies have shown, on the contrary, that parents' involvement in their children's education has a generally positive effect on their academic performance (Cabus \& Ariës 2017; Fehrmann, Keith \& Reimers, 1987; Jeynes, 2005). And there are also studies that provide evidence that home-educated children perform better academically (Ray, 2010; Rudner, 1999). For example, MartinChang, Gould and Meuse (2011) found that children who were schooled at home through a structured educational process attained better results in standardised tests compared to students who attended a public school. A study by Cavanaugh et al. (2004) found that students can attain similar academic results through distance education to those obtained through the traditional mode of education. A key question, however, is what effect remote learning on a mass scale might have in households where the parents have not voluntarily chosen this mode of education and where 
remote learning is moreover taking place during a crisis, which is what the COVID-19 pandemic is.

As well as concerns about the effectiveness of distance education, there are also worries about whether this mode of education will increase the differences in the educational opportunities of students from different social backgrounds (Andrew et al., 2020) For example, Reimers and Schleicher (2020) note that there are differences in the educational conditions in students' households, potential differences in the ability of schools to support distance education, and, last but not least, differences between the children themselves and their level of resilience, motivation, and ability to learn independently and online. These concerns have already been validated by some empirical studies (see Engzell et al., 2020).

As well as the possible negative effects of the COVID-19 pandemic on education, some unexpected positive effects can be identified. Reimers and Schleicher (2020) cite the introduction of technology and innovation in education, the increased independence of students in learning, a strengthening of the relationship between the school and the family, the greater autonomy of teachers, and more. Barhoumi et al. (2020) primarily observed a higher degree of independence among students and advances in their digital skills. Parents have also noticed their children displaying greater autonomy, and two-thirds of parents believe that their children have not only been able to maintain their level of learning but have also discovered new learning methods.

\section{The Situation in the Czech Republic}

In March 2020 the Czech government announced a state of emergency on the grounds of the health risk. Under it, students were prohibited from being physically present in schools and remote home-based learning was mandated, which, with a few interruptions, has continued to the present day (April 2021). The only exception has been students in Years 1 and 2 of primary school (ČŚI, 2021), who have been taught in the classroom for most of this period (ibid.). While the schools have been closed, remote learning has been supported by the Ministry of Education, which launched a website providing schools, teachers, students, and parents with up-to-date information and support. Educational support is also provided by the Czech School Inspection Agency (Česká školní inspekce, ČŠI), which publishes numerous thematic reports based on empirical surveys and provides information on the current situation, offers schools feedback, and publishes recommenda- 
tions. Czech schools nevertheless operate with a high degree of autonomy (Dvořák, 2011; OECD, 2020; Trojan, 2011), which in practice could mean that the remote learning varies significantly between schools, depending on the school's resources and the initiative of the school's administration and teachers (Švaříček et al., 2020).

The latest report from the Czech School Inspection Agency released in March 2021 (ČS̆I, 2021) reveals that during the school closures Czech primary schools were unable to make contact with approximately 10,000 students (from a total of 953,000 students), who therefore had no education during this time. The report also shows that after the schools were closed in the spring of 2020, around 250,000 students did not take part in synchronous online learning for technical reasons, although they were provided with learning materials and assignments by the school through some other means. In the autumn this number had decreased to around 50,000 students, because the schools were by then better prepared for online teaching (ibid). These findings are consistent with the results of the representative PAQ survey (2020), which revealed big differences in the methods of online learning in the spring and autumn of 2020. Unlike the situation in the spring, in the autumn schools made much more frequent use of synchronous online learning tools, gave students more assignments, managed to cover more learning material, increased the frequency of assessments, and made more frequent use of a single online communication environment, making things clearer for the students. Consequently, the total amount of time that students spent on learning increased from 3.7 to 5.3 hours a day (PAQ, 2020).

The Czech School Inspection Agency (2020) survey of students feelings about remote at-home learning found that they liked the flexibility of it, the opportunity to adapt the organisation and pace of learning to their own needs and capacity, and the efficiency of it. Students also positively viewed the ability to get feedback from their teachers. Conversely, they least liked the fact that they were not able to see their classmates and had to sit at home in front of the computer. Parents' views on remote learning in the home were examined by Brom et al. (2020), Smetáčková, Štech (2021) and Švařičck et al. (2020). These authors identified big differences between children at different education levels. While parents of children at the primary level were helping their children for $40-60 \%$ of the time the children spent learning, the percentage for children at the lower-secondary level was much lower, at $40 \%$ or less. Parents of children at the primary level generally considered the assignments children were given by the school to be more 
useful than parents of children at the lower-secondary level did. They were also less involved in their children's education. The authors suggest that the lower-secondary curriculum is more academically demanding and that parents may begin to feel that they are not able to help their children with their schoolwork.

As Peek and Richardson note (2010, p. 63): 'Children may experience psychological, physical, and educational vulnerability as the result of a disaster. Of these 3 vulnerability types, educational vulnerability has received the most limited scholarly attention.' This article seeks to contribute to our understanding of how, amid the school closures aimed at preventing the spread of COVID-19, Czech families have coped with remote learning in the home environment, what barriers they think remote learning presents and what are its advantages. This is one of the first pilot studies employing a qualitative design and structured interviews to examine this issue in depth. Previous Czech studies have relied on quick and simple surveys or questionnaires that highlighted individual stakeholders' problems with remote learning.

\section{Research Methodology}

\section{Method(s) and research sample}

The aim of our research is to identify the problems that working parents may have to deal with in the course of involuntary remote home-based education. In this study, we decided to focus specifically on highly educated families with at least one child attending primary school, while in the follow-up studies we will focus on families with a lower level of academic education and with children at different education levels. We believe that parental education is crucial to how parents dealt/coped with home-based education. We therefore decided to distinguish between parental education level in our study of family experiences of remote learning. Similarly, it can be expected that the child's age affected home-based education practices during the pandemic. In this first study, we therefore concentrated solely on families with primary school children. As we wanted to gain more in-depth insights, we chose a qualitative approach. Qualitative methods are used to reveal and understand phenomena that we do not know very much about (Strauss \& Corbin, 1990).

To begin with, we defined the sample frame by specifying the inclusion criteria for family participation in the study (Robinson, 2014). The selection 
criteria were: a high level of education (at least one of the parents has a university degree), a two-parent family living in the city with at least one child attending primary school, and both parents had to be employed at least part time before the pandemic. We used theoretical sampling as defined by Glaser and Strauss (1967). Our final research sample consisted of eight families represented by 'participants', all of whom were women (mothers) with a university degree. We placed a repeat advertisement on the department website in February 2021 asking for families to participate, and distributed it through our students as well. Information on the research sample is presented in Table 1.

Table 1 Characteristics of the research sample

\begin{tabular}{|c|c|c|c|c|c|c|}
\hline ID & $\begin{array}{l}\text { Mother's/ } \\
\text { father's } \\
\text { education }\end{array}$ & $\begin{array}{c}\text { Mother/ } \\
\text { father } \\
\text { working from } \\
\text { home }\end{array}$ & $\begin{array}{l}\text { No. of } \\
\text { children in } \\
\text { the family }\end{array}$ & $\begin{array}{l}\text { Student } \\
\text { gender }\end{array}$ & $\begin{array}{c}\text { School } \\
\text { year }\end{array}$ & SEN \\
\hline $\mathbf{A}$ & Tert./Tert. & yes/no & 2 & boy & 2 & yes \\
\hline $\mathbf{B}$ & Tert./Tert. & $\mathrm{ML} / \mathrm{no}$ & 3 & girl & 1 & no \\
\hline $\mathbf{C}$ & Tert./Sec. & yes/no & 2 & boy & 1 & no \\
\hline D & Tert./Tert. & yes/no & 2 & boy & 5 & no \\
\hline $\mathbf{E}$ & Tert./Tert. & yes/no & 2 & boy & 1 & no \\
\hline $\mathbf{F}$ & Tert./Tert. & yes/no & 2 & girl & 2 & no \\
\hline $\mathbf{G}$ & Tert./Tert. & yes/no & 2 & boy & 2 & no \\
\hline $\mathbf{H}$ & Tert./Tert. & yes/yes & 1 & girl & 4 & no \\
\hline
\end{tabular}

Notes: ML: Maternity leave, SEN - special educational needs

Data collection and analysis

The data were collected using in-depth semi-structured interviews carried out in February and March 2021. Because of the government regulations, all the interviews were conducted online through a platform.

Before the interviews were carried out, the structure of the interview thoroughly prepared, assessed by experts, and piloted. The interviews lasted 40-45 minutes on average. All the interviews were recorded and then transcribed verbatim.

Approaches inspired by grounded theory were used in the analysis. The data concepts (Glaser \& Strauss, 1967) were identified using open, axial, and selective coding (Strauss \& Corbin, 1990). We searched for relation- 
ships between concepts (codes, categories, and their thematic patterns). Specifically, this meant that we integrated the concepts we discovered so that they fit the following logic: the phenomenon's causal conditions, its context (characteristics and dimensions), (intervening) conditions, actions (strategies) and consequences (Strauss \& Corbin, 1990). As part of the focused (Charmaz, 2006) or selective (Strauss \& Corbin, 1990) coding, we concentrated on narrowing the focus of the research question and on substantiating the choice of the central concept (Glaser \& Strauss, 1967). Although the resulting theory is based on an interpretive understanding of empirical phenomena, our aim was to devote as much time as necessary to discovering the most logical explanations (i.e. ones grounded in data), and not making speculative conclusions (Glaser \& Strauss, 1967).

The technical process of coding was conducted using the text editor's organisational tools (Řiháček \& Hytych, 2013). During each level of the coding process, we continued to make notes (memos) in order to capture any ideas that could prove useful for the emerging theory. One important approach was the method of constant comparison, which involves systematically collecting, evaluating, and analysing data so that they can stand as evidence of the proposed theory that is trying to show under what conditions a phenomenon applies (Glaser, Strauss, 1967).

We followed the principles of confidentiality and respect for the participants and their families. At the start of the online interview, the participants were shown a detailed informed consent form on a shared screen. Participation in the research was voluntary and the participants were offered no incentives to take part in the research. All the data were anonymised during the transcription process and each participant was assigned a letter from A to $\mathrm{H}$. The audio-visual recording was erased after the interview had been transcribed.

\section{Results}

Under the COVID-19 school closures, the government's strategy was to continue education provision through remote home-based education. This created an unprecedented situation for families. Parents had to tackle a series of issues, including finding a way to ensure the continuation of their children's education, taking care of them, while performing their job at the same time. The interviews with our participants revealed that the families relied mainly on the mother, who assumed the primary responsibility for educating the children and taking care of the household. This strategy was 
made possible by the fact that during the pandemic all the mothers - the participants - were able to work from home for at least part of their working hours or temporarily changed their work contract from full time to part time. Most of the fathers continued working full time, mostly outside the home.

\section{Factors that influenced mandatory home-based learning}

How families tackled home-based education depended on several factors (intervening variables). These included the school's approach towards remote home-based learning (namely the quality of the remote education offered by the school and the communication between the school and the parents), the parents' ability to devote time to home-based teaching, the child's characteristics, the number of children in the family, the parents' teaching skills, the material, technical and spatial features of the household, and the situation in the family and society.

One of the key factors affecting remote home-based education was the school's approach. Although remote home-based education resembled the usual model of home education/homeschooling (it was based in the home and the parents were substantially involved the education process), there were some important aspects that differed - above all, it was mandatory and it was conducted under the direct guidance of the schools. Under Czech law, families who adhere to the usual model of home education are only obliged to follow the general curriculum outline and requirements but are otherwise quite free to adapt the lessons to the child's and the family's needs ${ }^{2}$. By contrast, under the remote home-based education during the pandemic, families had to closely coordinate all their educational activities with the schools. Our participants were ambivalent about this; some evaluated it negatively and others positively. Parents either thought the school was constraining their activities and limiting their freedom, or they appreciated being able to delegate some education-related activities to the school and save some time for other family activities and duties.

The older one had more school assignments as he was already a fourthgrader. He received homework on a day-to-day basis, so one day he had nothing to do and the other day he had a lot of work, simply too much. So, we couldn't plan his workload, do something in advance on some

\footnotetext{
2 For more information on the usual model of home education in the Czech Republic, see Belán̆ová at al. (2018, 2020), Hána, Kostelecká (2020), Machovcová at al. (2021), Kašparová (2021), Kostelecká at al. (2021), Kostelecká (2017).
} 
days and take a day off and go on a trip on another day, sometimes just for our basic mental well-being. We were always at home together, four people, from dawn until dusk, and with all that teaching... (D)

Currently, my child has online teaching as the standard, plus he receives assignments through various web platforms, but I have a feeling that the children are already so well trained that they can handle it on their own. (H)

The effectiveness of the mandatory remote home-based education strongly dependended on the cooperation and communication between the school and the family. However, the participants' statements revealed that there were significant differences between schools. Some participants praised the communication and feedback they got from teachers, whereas other participants considered the communication to be insufficient, and in some cases there was almost no communication or cooperation and almost no individual feedback.

It's like this, our school principal is excellent as a politician, and the foundation of our school, he's always saying, is communication. He was communicating with parents from the very start, all the news, everything that was going to happen, we knew it, and he has this, I'd say, common sense, so he's a really good manager. $(F)$

'Individual assessments ... there weren't any' (C)

In some cases, participants mentioned differences between the school administration's approach and that of the teachers. For example, the school administration did not communicate with parents at all, while the teachers' communication with parents was considered very good.

The school as such barely communicated with us at all. From time to time, something appears on the school web and the web page is so outdated and chaotic that you can hardly call it communication. But the teacher himself, the communication with him was very good. (A)

Another important factor affecting the effectiveness of the learning process during the COVID-19 pandemic was the quality of the education provided by the school, as perceived by the parents. Most schools offered a combination of offline and online learning that included the use of synchronous online learning tools. The amount of education provided through one or other of 
these two modes changed over time, with the greater part of teaching being provided through online learning tools, which led many parents to evaluate the spring and autumn remote home-based education very differently.

When I look at it, there's a polar difference between the spring and the autumn. (H)

The participants stated that during the spring school closures there was almost no synchronous online learning at their school. Consequently, the parents had to provide most of their children's education on their own. They worked together with their children on the assignments they had been given by the school.

In the spring, I think we were all taken by surprise, so there was some form of online learning in the spring, but looking back I'd say 85 percent of it was up to the parents. (H)

Some participants said that when the school provided synchronous online learning in the spring, the teachers and children were not well prepared for it. In some cases, the parents had to advise the teachers on how to use some of the online learning tools.

Then we, the parents, started to tell the teacher what could be done differently, as she didn't understand how to use the technical equipment and software, (...), she didn't know that the screen could be shared or that, for example, it's possible to take a picture of the textbook page and share it with all the pupils... But she didn't even have a system for giving the children the floor and letting them speak, so some children were bored, some children were given the opportunity to talk repeatedly, while she forgot about others. (C)

In the autumn, the situation was different. The participants described the schools as being much better prepared during the autumn closures, and said that in most cases synchronised learning took place, and some parents applauded this.

And later, when it happened, there was a tremendous difference. It's really a much greater help to the family when the children have lessons with the teacher at least some of the time. They get feedback, they see their classmates, though it's not ideal, but at least something like that online was a great help for me and for the children as well. (D) 
The schools' move towards more synchronised online learning was aimed at making the parents' situation easier and relieving them of some of the burden placed on them during the school closures. It was also meant to make the children's learning more effective and help schools to regain control over the teaching process. Although some parents appreciated this, because it allowed them more time for their work and daily activities, others did not for various reasons. The data showed that synchronous online learning proved to be very challenging for children in the first years of schooling. Although some children learned very quickly to work in the synchronous online environment, others (especially children with special educational needs) needed a lot of help from their parents.

He didn't need our help. On the contrary, he shooed us away - we weren't to talk to him about it, we weren't to help him. After the second hour, for example, he was able to turn the microphone on and off himself, operate online teaching tools on the computer, and I think he managed it just fine. (G)

He needed help with everything, he wasn't able to manage at all. So, I would get him online, he'd sit there, I'd sit with him, I'd turn the microphone on and off for him, because when he did it himself it would take him forever to even find the button (...) at most he was just sitting there and speaking. (A)

The participants also highlighted a number of other potentially problematic aspects of synchronous online learning. One issue was how much of the overall teaching was provided using this form of learning. The participants' statements indicate that some schools simply 'transplanted' the timetable usually used in the classroom to the synchronised online learning environment. As a result, some children had difficulty maintaining their attention and following the lessons.

The school was trying to get the children to study according to the timetable, classes really started at 8 in the morning and ended according to the timetable, and except for PE and art the children did all their subjects. $(H)$

For some children the lessons were not very appealing and were too long and sometimes stressful. Younger children in particular had trouble adhering to the rules of communication. 
These children aren't able to follow that, they aren't able to pay attention and mainly they aren't able to follow the rules of communication in this online environment. This means that when someone is asked to speak, the others should stay silent and wait until someone says something. They weren't able to do that at all, they spoke immediately talking over each other, it was extremely chaotic for me and for my son as well, so we left. (A)

Some participants felt that the effectiveness of the learning was undermined by the fact that a large part of the lesson was taken up with organisational matters and dealing with unsubmitted homework.

And what bothers me the most is that the teacher (...) spent half an hour of the Czech language lesson scolding the pupils who had not done their homework. (D)

Some participants also felt that there was little time left for teachers to take an individual approach and little room for individual work and that over time the children were losing the motivation to do their schoolwork.

So, it's something of a problem that there is no space at all for an individual approach. The teachers really try to accommodate the weakest students, which is good, but on the other hand the motivation of the whole class is really affected by this, the children who are more advanced are really bored. (D)

However, parents did not only find home education challenging because of the school's approach, but also because of the other intervening factors mentioned above. One significant factor was the number of children in the family: the more children in the family, the greater the demand for space and technological equipment, not to mention the childcare and housework and the need for assistance with the lessons.

There was a bit of a problem with equipment and space, because my husband was also working from home, now he's going to work as usual again, but in the flat there was almost no room without someone in it. So, one in the kitchen, one in the little room, one in the bedroom, and then there may be no room left for me. (D)

Another important factor was the age of the children: the younger the child, the less independent they are when learning and doing online lessons. 
the family's socioeconomic status also matters - the parents' education level, financial and material circumstances, type of job, whether they can work from home or reduce their hours to part time. Many mothers stated that their various roles as employee - mother - earner clashed with one other and this and the severe shortage of time was often a great source of stress in the family as a whole.

I was a teacher, a maid, a cook, because simply by not being at school for lunch meant a huge amount of work, you're constantly cooking, and doing homework, and there was no time for my work, except maybe in the evening or at night. (D)

The parents' teaching skills also played a role. Although the participants were highly educated and generally stated that they had no problem mastering the learning content, some of them questioned their teaching skills and ability to motivate their children to learn.

I don't know how to teach him to read because I just don't know. I can read, but I don't know how to teach it. (E)

Finally, it was clear from the participants' statements that the difficult situation was further exacerbated by the direct effects of the COVID-19 pandemic on the family.

When it broke out, in October, the day right before that my father had died, so no one saw how we collapsed (...) Because we tested positive, me and the kids, so only me and my husband, we alternated, I felt truly awful (...) But really sitting down and doing it with her the entire time, that wasn't possible with us. Because my husband was afraid that he'd catch it, he's in a risk category, and I was afraid that I was going to give birth at any moment, and I have to say that COVID-19 in the ninth month [of pregnancy] is not exactly the best combination. (B)

Strategies that helped parents cope with the situation

Families tried to cope with the demanding mandatory home-based learning in different ways. We found that the goal of the parents in our cohort was not only to ensure the continuity of their children's education, but also to improve the well-being of the children and the family as a whole. Strategies for coping with education included adapting work responsibilities to the new situation - reducing work hours, working from home, working when possi- 
ble within the limits of family responsibilities. This also meant ensuring the necessary technical equipment was available, parents' preparing their own learning materials for the children, teaching children outside the scope of online education in terms of both time and content, alternating with a partner in helping the children with learning, and providing additional instruction or individual language group lessons.

I prepared things in the evening. Because I wanted to give him these things, what they were getting was all assignments on this or that page, this or that many exercises, and I didn't like giving him it just that way. So I'd prepare these exercise pages for writing, which were completely different from the mindless writing they have in their copybook. I searched for things on the internet, different exercises that were more entertaining than the standard ones that are taught. (A)

If the children had difficulty mastering synchronous online learning, their parents helped them to make sure they were able to participate in the lessons. In addition, if the children did not find the lessons appealing, the parents tried to motivate them to pay attention, listen to the teacher, and study.

I sat next to him the entire time, I followed the teaching, and I did all the technical operations for him. (A)

Parents also tried to improve the well-being of their children and the family as a whole. They tried to find new ways for the family to spend its leisure time and relax.

We spend time together anyway, we just go on trips, to the cottage, maybe we have more time for the board games we bought. We have more time for them now, so we play together more often. (G)

The participants also tried to find ways of making up for the absence of hobby and sports groups and other activities that their children would have been engaged in under ordinary circumstances. However, they could not be fully accommodate the children's need for social contact with friends and other children. Although attempts were made to do so at least partially.

If I were to say, we regularly see two other families with children, continuously and constantly and we spend our time quite actively, so just now we've been cross-country skiing for two months, while the kids are 
small, they got skis and we were skiing, we went out on our skies on weekends. (F)

Regarding the role of parents in education, all participants found that this way of learning places much greater demands on the parents, who have to be much more involved in their children's education than under normal circumstances. At the same time, participants had different views on the mandatory home-based education, depending on the situation in each family.

I think it was great, the teacher was perfect. (G)

I think that classroom learning at the school is more effective, for sure (...) the way learning was organised now, that's not the way forward, it was really a waste of time for everybody (...), especially when I compare it with the first week, when I taught him myself. I said to myself that if I was able to teach him on my own, he'd just learn much more, it would be far more effective than that. (C)

And the main thing, a teacher teaching is completely different from a lesson from two annoyed parents who have to cook something as well as teach and, that's nothing like real teaching (...) Teachers have time for this. Time and the peace of mind, and the child will do their best in front of the teacher, but not in front of their parents, as we irritate them. (B)

However, the parents agreed on certain positive aspects of home education - the children did not have to get up early and get ready to go to school, the parents had a better picture of what and how their children learn at school, which they consider very important and in some cases they are now more appreciative of what teachers do for their children.

We discovered how the teaching works, that the teacher is a saint, that it's not easy at all. (G)

In addition, some parents believe that their children gained more independence during their home-based education.

I also see a lot of progress in his independence, there are actually days when we are both working, so our child is on his own, and he's actually able to change the whole lesson, do his homework, record his tasks, study what he has to. So this is a big step forward. (H) 
In conclusion, it is important to note that this experience led some parents to believe that in certain circumstances - for instance, if a child were ill, or for some other reason could not attend school instruction - it would be useful to combine learning modes so the child could learn partly at home and partly at school.

\section{Discussion and Conclusion}

The school closures in response to the COVID-19 pandemic brought rapid and deep changes to family life (Sevilla $\&$ Smith, 2020). The aim of this study was to examine how Czech families with primary school children dealt with this situation. From our analysis of the in-depth interviews, we can generally state that the families that participated in the study found functional solutions so that their children could continue learning while they could get on with their other work responsibilities. Similar conclusions were reached in quantitative studies by Brom et al. (2020) and Švařiček et al. (2020). Our analysis also revealed that there were big differences in the home-based learning during the spring and autumn 2020 school closures. During the spring closures some schools were not sufficiently prepared for home-based learning. Parents, however, appear to have been less critical of the schools at that time (PAQ, 2020). Moreover, the prevailing view in the spring was that this was just going to be a short-term situation and the children would return to school after several weeks. As a result, some of the families in the study were not very stressed about it and instead enjoyed some of the advantages of the situation - most notably, the chance to spend more time together as a family, stay at their cottage, go out in the countryside, etc.

Throughout the school closures children were assigned schoolwork through various online apps and by other means as well, such as by telephone or in person. It was generally assumed that, with the younger school-age children at least, the parents would help the children with their school assignments. Most of our participants not only organised their children's learning and administered it, they also provided learning support (e.g. helped them get online, checked their assignments). Although during the spring school closures, the schools focused more on reviewing and repeating learning material that had already been covered (ČS̆I, 2021), the home-based learning process was very time-demanding on mothers. While some participants were from the very start of the school closures appreciative of how and how often the schools communicated with them during the crisis, many others claimed that the school had failed in its communication and the parents lost trust in the school administration as a result. A key 
condition for successful cooperation between schools and parents was good communication with the students. The participants complained that the schools used numerous different platforms for communication, which made the situation much more complicated. Students did not know where to look for their assignments or how and when to submit their work, etc. Even the Ministry of Education was forced to recommend that schools use just one communication platform (MŠMT, 2020). This situation had greatly improved by the autumn (PAQ, 2020; ČS̆I, 2021).

According to the participants, there was proportionately less synchronous online education in the spring than in the autumn, and other sources confirm this (ČS̆I, 2021; PAQ, 2020). When synchronous online learning did take place, the quality fell short of expectations. It transpired that some teachers did not know how to use the online tools, which made this mode of learning less effective. Some participants even claimed that parents were giving some teachers advice during online learning and explaining how to use ICT technologies and the online environment. Some students also had difficulty with the online learning, mainly the youngest ones, many of whom needed their parents' help because they were not able to operate the online learning system on their own. By the autumn this situation had changed considerably. Both the amount of synchronous online learning increased and the ICT technology skills of parents and children improved, with many schools teachers and students having received intensive training in this area (ČŠI, 2021). Although some of our participants had hoped that this mode of learning would result in some of the responsibility for the children's learning being transferred back to the schools and that the quality of the learning process would improve, these expectations were not always fulfilled. Despite the fact that the synchronous online learning took place in smaller groups so that the teacher could focus individually on students, some participants noticed a number of shortcomings. The main one was that young schoolage children needed various degrees of parental assistance during online learning. Some children were also unable to communicate in the online environment - they often talked over one another. Some children found this mode of learning unengaging, and it was therefore difficult to maintain their attention. In some cases, the participants said the children spent too much time on synchronous online learning - initially some schools had simply 'transplanted' the class timetable into the online environment (PAQ, 2020). This turned out to be a bad idea as intensive use of ICT technologies without a break is a risk factor for mental health and sleep problems (Thomée, 2012). The Ministry of Education responded by issuing recommendations on the appropriate use of synchronous online learning (MŠMT, 2020). The 
increased amount of synchronous online learning nevertheless seems to have resulted in more time being spent on dedicated learning and a larger volume of learning material being covered (PAQ, 2020).

The participants were also somewhat critical of the effectiveness of the synchronous online learning. They especially noted the large amount of time teachers spent checking submitted assignments and disciplining children during class-time. Parents also felt that in the online environment teachers could not respond effectively to the individual needs of the children. Although teachers were much better at mastering the information technology and online communication applications in autumn 2020, they seemed to lack the soft skills associated with learning in an online environment to make effective use of teaching time, keep children's attention, and pay attention to individual educational needs. However, the data show that the synchronous online learning did save participants a considerable amount of time. Generally, the participants concurred that online learning and homebased learning as a whole had given them a much better idea of what the children learned and how and had improved the children's ICT technology skills.

It is worth noting that, even though all the participants found themselves in a basically similar situation (they unexpectedly had to become their children's teachers), other intervening factors influenced their experiences to the extent that they evaluated the experience and its outcomes in very different ways. Moreover this was the case despite the families we interviewed having very similar socio-economic and demographic characteristics - they were all highly educated working parents with at least one child at primary school.

\section{Supervising afternoon activities}

The participants not only oversaw their children's online learning, they also had to organise their children's leisure time. While we know that the lockdown was accompanied by significant restrictions on how free time can be spent, and this could mean the children were not getting enough physical activity (Lee et al., 2021), in reality it appears from the interviews that many families found ways out of this situation. Some families moved to their cottage, where the children were able to spend their time off in the countryside on the weekends, while others stated that they spent a lot of time skiing, and yet others spent time in the garden. Some participants noted that despite the social distancing regulations their children had met up with friends in 
their neighbourhood during the school closures. Brooks et al. (2020) show, on the basis of a meta-analysis, that there are indications that many children continued to leave their home and meet up with others even when society was trying to minimise social contact. Nevertheless, it was possible for children to maintain social contact through epidemiologically safe means. While the schools were closed children spent a lot of time on social media, and others communicated with their classmates during the synchronised online learning. Many of the participants nonetheless declared that their children had lacked social contact and missed their friends.

\section{Conclusion}

Parental involvement in their children's learning has been found to have significant positive effects on academic attainment (Cabus \& Ariës 2017; Fehrmann, Keith \& Reimers, 1987; Jeynes, 2005). Studies have shown that home-educated children perform better academically than children educated in the classroom (Ray, 2010; Rudner, 1999; Martin-Chang, Gould \& Meuse, 2011) and that the academic attainment of children schooled remotely during crises is satisfactory (Cavanaugh et al., 2004). Despite all that, the mass provision of mandatory remote home-based education does not necessarily have positive outcomes, and there is a risk that children's academic performance deteriorates and the gap (Kuhfeld et al., 2020) between children's educational opportunities increases (Gould et al., 2020). Clearly, some of the risks cited here could be eliminated by implementing the right policies (Reimers \& Schleicher, 2020) or by using alternative methods of social distancing besides school closures (Uscher-Pines et al., 2018).

\section{Limitations of the Study}

This is a qualitative study, the results of which cannot be generalised because the sample of participants is not representative. The participants signed up for the study at their own initiative. Parents with higher education are over-represented in the sample, and this could have a significant influence on how they view and deal with home-based education. For example, almost all the participants, especially the parents of primary school children, stated that they were not worried about being able to cope with the content of the learning materials. Also, during the school closures almost all of the participants were working from home, which is generally more possible for those in better educated and better paid occupations (Bartik et al., 2020). Nonetheless, in February 2021 only $17 \%$ of the Czech population was working from home, while among higher-level professionals this figure was 
higher (33\%; see Tuček 2021). It is generally the case that more educated parents are less at risk of losing their job and have more opportunities to work from home (Bansak \& Starr, 2021).

\section{Acknowledgements}

This work was supported by the Czech Science Foundation under Grant number 21-21743S.

\section{References}

Andrew, A., Cattan, S., Costa Dias, M., Farquharson, C., Kraftman, L., Krutikova, S., Sevilla, A. (2020). Inequalities in Children's Experiences of Home Learning during the COVID-19 Lockdown in England. Fiscal Studies, 41(3), 653-683.

Bansak, C., \& Starr, M. (2021). Covid-19 shocks to education supply: how 200,000 US households dealt with the sudden shift to distance learning. Review of Economics of the Household, 19(1), 63-90.

Barhoumi, M. and Blouet, L., Charpentier, A., Cristofoli, S., Fréchou, H., Hubert, T., Iasoni,E., Lermite, A., Michaudon, H., Moyère, R., Odin-Steiner, D., Raffaëlli, Ch., Solnon, A., Stefanou, A., Touahir, M., Traore, B., Wuillamier, P. (2020). Health crisis of 2020 and pedagogical continuity: the students have learned satisfactorily, DEPP-B. Bartik, A. W., Cullen, Z. B., Glaeser, E. L., Luca, M., \& Stanton, C. T. (2020). What jobs are being done at home during the COVID-19 crisis? Evidence from firm-level surveys (No. w27422). National Bureau of Economic Research.

Belán̆ová, A., Machovcová, K., Kostelecká, Y., \& McCabe, M. (2018). Justifying homeschooling in Czech Republic: How "good parents" and their children use time. Childhood, 25(4), 530-543.

Belán̆ová, A., Kostelecká, Y., Machovcová, K., \& McCabe, M. (2020). 'Twofold otherness': on religion, spirituality, and home schooling in the Czech Republic. Journal of Beliefs \& Values, 41(4), 406-418.

Bozkurt, A., \& Sharma, R. C. (2020). Emergency remote teaching in a time of global crisis due to CoronaVirus pandemic. Asian Journal of Distance Education, 15(1), i-vi. Brom, C., Lukavský, J., Greger, D., Hannemann, T., Straková, J., \& Švařiček, R. (2020). Mandatory home education during the COVID-19 lockdown in the Czech Republic: A rapid survey of 1st - 9th graders' parents. Frontiers in Education, 5, 103. Brooks, S. K., Smith, L. E., Webster, R. K., Weston, D., Woodland, L., Hall, I., \& Rubin, G. J. (2020). The impact of unplanned school closure on children's social contact: rapid evidence review. Eurosurveillance, 25(13), 2000188.

Cabus, S. J., \& Ariës, R. J. (2017). What do parents teach their children? - The effects of parental involvement on student performance in Dutch compulsory education. Educational review, 69(3), 285-302.

Cavanaugh, C., Gillan, K. J., Kromrey, J., Hess, M., \& Blomeyer, R. (2004). The effects of distance education on $k-12$ student outcomes: A meta-analysis. Learning Point Associates/North Central Regional Educational Laboratory (NCREL). 
Cooper, H., Nye, B., Charlton, K., Lindsay, J., \& Greathouse, S. (1996). The effects of summer vacation on achievement test scores: A narrative and meta-analytic review. Review of educational research, 66(3), 227-268.

ČŠI (2020). Zkušenosti žáků a učitelủ ZŠ s distanční výukou ve 2. pololetí 2019/2020. Tematická zpráva. Praha: Česká školní inspekce.

ČS̆I. (2021). Distanční vzdělávání v základnich a stredních školách Přistupy, posuny a zkušenosti škol rok od nástupu pandemie nemoci covid-19. Tematická zpráva. Praha: Česká školní inspekce.

Dvořák, D. (2011). Pedagogické vedení školy: hledání zdrojů a obsahu pojmu. Orbis Scholae. 5(3):9-25.

Engzell, P., Frey, A., \& Verhagen, M. D. (2020, October 29). Learning inequality during the COVID-19 pandemic. https://doi.org/10.31235/osf.io/ve4z7.

Fehrmann, P. G., Keith, T. Z., \& Reimers, T. M. (1987). Home influence on school learning: Direct and indirect effects of parental involvement on high school grades. The Journal of Educational Research, 80(6), 330-337.

Glaser, B. G., \& Strauss, A. L. (1967). The discovery of grounded theory: Strategies for qualitative research. Chicago, IL: Aldine.

Gouëdard, P., B. Pont and R. Viennet (2020). Education responses to COVID-19: Implementing a way forward. OECD Education Working Papers, No. 224, OECD Publishing, Paris.

Gould, E. D., Simhon, A., \& Weinberg, B. A. (2020). Does parental quality matter? Evidence on the transmission of human capital using variation in parental influence from death, divorce, and family size. Journal of Labor Economics, 38(2), 569-610.

Hána, D., \& Kostelecká, Y. (2020). A comparison of home education legislation in Europe from the perspective of geography of education. Research Papers in Education, 1-30.

Holloway, D., Green, L., \& Livingstone, S. (2013). Zero to eight: Young children and their Internet use. London, England: EU Kids Online. http://eprin ts.lse. ac.uk/52630.

Charmaz, K. (2006). Constructing grounded theory: A practical guide through qualitative analysis. sage.

Jeynes, W. H. (2005). A meta-analysis of the relation of parental involvement to urban elementary school student academic achievement. Urban education, 40(3), 237-269.

Kašparová, I. (2021). Homeschooling as a Barometer of State Power and Control in the Czech Republic. In Global Perspectives on Home Education in the 21st Century (pp. 250-266). IGI Global.

Kostelecká, Y., Kostelecký, T., Belán̆ová, A., \& Machovcová, K. (2021). Home-Education in Czechia: Twenty Years of Experience. In Global Perspectives on Home Education in the 21st Century (pp. 139-158). IGI Global.

Kostelecká, Y. (2017). Home education experience in selected post-communist countries. The Wiley handbook of home education, 422-445.

Kuhfeld, M., Soland, J., Tarasawa, B., Johnson, A., Ruzek, E., \& Liu, J. (2020). Projecting the potential impact of COVID-19 school closures on academic achievement. Educational Researcher, 49(8), 549-565.

Lee, S. J., Ward, K. P., Chang, O. D., \& Downing, K. M. (2021). Parenting activities 
and the transition to home-based education during the COVID-19 pandemic. Children and Youth Services Review, 122, 105585.

Machovcová, K., Beláňová, A., Kostelecká, Y., \& Mccabe, M. (2021). Homeschooling mothers: Precarious by choice?. Human Affairs, 31(1), 73-88.

Martin-Chang, S., Gould, O. N., \& Meuse, R. E. (2011). The impact of schooling on academic achievement: Evidence from homeschooled and traditionally schooled students. Canadian Journal of Behavioural Science/Revue canadienne des sciences du comportement, 43(3), 195.

MŠMT (2020) Metodické doporučeni pro vzdělávání distančnim způsobem. Praha.

OECD (2020), TALIS 2018 Results (Volume II): Teachers and School Leaders as Valued Professionals, TALIS, OECD Publishing, Paris.

PAQ (2020). Distančni výuka na jaře a na podzim. Výsledky reprezentativního kvantitativního výzkumu 2020. PAQ Research.

Parczewska, T. (2020). Difficult situations and ways of coping with them in the experiences of parents homeschooling their children during the COVID-19 pandemic in Poland. International Journal of Primary, Elementary and Early Years Education, 3-13, 1-12.

Peek, L., \& Richardson, K. (2010). In their own words: Displaced children's educational recovery needs after Hurricane Katrina. Disaster Medicine and Public Health Preparedness, 4(S1), S63-S70.

Ray, B. (2010). Academic achievement and demographic traits of homeschool students: A nationwide study. Academic Leadership: The Online Journal, 8(1), 7.

Reimer, D., Smith, E., Andersen, I. G., \& Sortkær, B. (2021). What happens when schools shut down? Investigating inequality in students' reading behavior during Covid-19 in Denmark. Research in Social Stratification and Mobility, 71, 100568.

Reimers, F. M., \& Schleicher, A. (2020). A framework to guide an education response to the COVID-19 Pandemic of 2020. OECD. Retrieved April, 14(2020), 2020-04.

Robinson, O. C. (2014). Sampling in interview-based qualitative research: A theoretical and practical guide. Qualitative research in psychology, 11(1), 25-41.

Rudner, L. M. (1999). Scholastic achievement and demographic characteristics of home school students in 1998. Education policy analysis archives, 7(8), 1-33.

Řiháček, T., \& Hytych, R. (2013). Metoda zakotvené teorie. In Řiháček, T., Čermák, I. Hytych, R. Kvalitatiuni analýza textů: čtyři př́stupy (44-74). Brno: MU.

Sevilla, A., \& Smith, S. (2020). Baby steps: the gender division of childcare during the COVID-19 pandemic. Oxford Review of Economic Policy, 36(Supplement_1), S169-S186.

Shavers, A. W. (2005). Katrina's children: Revealing the broken promise of education. Thurgood Marshall Law Review, 31, 499.

Smetáčková, I., \& Štech, S. (2021). Obavy rodičů žáků 1. stupně základních škol: co ukázalo uzavření škol?. Studia paedagogica, 26(1), 9-38.

Strauss, A. L. \& Corbin, J. (1990). Basics of qualitative research: Grounded theory procedures and techniques. Newbury Park, CA: Sage.

Švaříček, R., Straková, J., Brom, C., Greger, D., Hannemann, T., \& Lukavský, J. (2020). Spolupráce rodiny a školy v době uzavřených základních škol. Studia paedagogica, 25(3), 9-41.

Thomée, S. (2012). ICT use and mental health in young adults. Effects of computer 
and mobile phone use on stress, sleep disturbances, and symptoms of depression. Institute of Medicine. Department of Public Health and Community Medicine. Institute of Medicineat Sahlgrenska Academy University of Gothenburg. University of Gothenberg. Gothenburg.

Trojan, V. (2011). Vzdělávání řídicích pracovníků v českém školství: programy a hodnocení jejich obsahu účastníky. Orbis scholae, 5(3), 107-127.

Tuček, M. (2021). COVID 19 a finanční situace domácností a dopad na zaměstnáníNaše společnost - speciál - únor 2021. Tisková zpráva. CVVM, SoÚ AV ČR. Praha.

Uscher-Pines, L., Schwartz, H. L., Ahmed, F., Zheteyeva, Y., Meza, E., Baker, G., \& Uzicanin, A. (2018). School practices to promote social distancing in K-12 schools: review of influenza pandemic policies and practices. BMC public health, 18(1), 1-13. Yamamura, E., \& Tsutsui, Y. (2021). Impact of closing schools on mental health during the COVID-19 pandemic: Evidence using panel data from Japan. ttp://arxiv.org/ pdf/2101.08476 arXiv:2101.08476.

\section{Authors:}

Yvona Kostelecká, Ph.D.

Department of Pedagogy

Faculty of Arts

Charles University

nám. Jana Palacha"

Prague

11638

Czech Republic

Email: yvona.kostelecka@ff.cuni.cz

Tereza Komárková, Ph.D.

Department of Pedagogy

Faculty of Arts

Charles University

nám. Jana Palacha"

Prague

11638

Czech Republic

Email: tereza.komarkova@ff.cuni.cz

Veronika Novotná, Mgr.

Department

Faculty of Arts

Charles University

nám. Jana Palacha"

Prague

11638

Czech Republic

Email: veronica.novotna@ff.cuni.cz 